\title{
Profil Pembunuhan di Kota Manado Tahun 2018-2019
}

\author{
Andrew P. Langelo, ${ }^{1}$ Erwin G. Kristanto. ${ }^{2}$ Nola T. S. Mallo ${ }^{2}$
}

\author{
${ }^{1}$ Program Studi Pendidikan Dokter Fakultas Kedokteran Universitas Sam Ratulangi, Manado, \\ Sulawesi Utara, Indonesia \\ ${ }^{2}$ Bagian Ilmu Kedokteran Forensik dan Medikolegal Fakultas Kedokteran Universitas Sam \\ Ratulangi, Manado, Sulawesi Utara, Indonesia \\ Email: andrew.langelo99@gmail.com
}

\begin{abstract}
The total risk of death due to homicide shows a tendency to decline in the past quarter century. However, the global homicide rate counted as a population proportion declines simply due to the incline of global population. This study was aimed to obtain the profile of homicides in Manado from 2018 to 2019. This was a descriptive and retrospective study with a cross sectional design using homicide case reports from 2018 to 2019. The results showed that there were 17 cases of homicides in 2018-2019 in Manado, predominated by violence in 15 cases $(88 \%)$. Most of the prepetrators were males $(94 \%)$, aged $17-25$ years (59\%). Moreover, all victims were males (100\%), aged 17-25 tahun (53\%). Of 17 cases, 13 cases were autopsied (76\%). In conclusion, homicides in Manado tends to decrease, but the death rate due to violence is still high enough. Moreover, most of the victims and perpetrators are students, therefore, a preventive action from the government as well as from the community and related institutions is needed.
\end{abstract}

Keywords: homicide profile

\begin{abstract}
Abstrak: Keseluruhan risiko yang mengalami kematian akibat pembunuhan terus menurun pada seperempat abad terakhir ini, namun, penurunan tingkat pembunuhan global yang dihitung sebagai proporsi populasi hanya disebabkan karena peningkatan populasi global. Penelitian ini bertujuan untuk mendapatkan profil pembunuhan di Kota Manado tahun 2018-2019. Jenis penelitian ialah deskriptif retrospektif dengan desain potong lintang dengan menggunakan laporan kasus pembunuhan di Polresta Kota Manado pada tahun 2018-2019. Hasil penelitian mendapatkan kasus pembunuhan pada tahun 2018-2019 di Kota Manado berjumlah 17 kasus, dengan kekerasan yang paling banyak terjadi ialah kekerasan tajam sebanyak 15 kasus (88\%). Pelaku terbanyak berjenis kelamin laki-laki (94\%) dan usia 17-25 tahun (59\%). Korban terbanyak berjenis kelamin laki-laki (100\%) dan dengan usia 17-25 tahun (53\%). Darii 17 kasustersebut, terdata 13 kasus yang diautopsi (76\%). Simpulan penelitian ini ialah angka pembunuhan di Kota Manado cenderung menurun, namun angka kematian akibat kekerasan tajam masih cukup tinggi serta mayoritas korban dan pelaku tergolong pelajar berjenis kelamin laki-laki. Untuk itu diperlukan suatu tindak pencegahan baik dari pemerintah maupun dari masyarakat dan institusi terkait.
\end{abstract}

Kata kunci: profil pembunuhan

\section{PENDAHULUAN}

Pembunuhan adalah kejahatan dengan hierarki tertinggi dalam klasifikasi kejahatan internasional yang memiliki efek berkelanjutan. Pembunuhan bukan hanya dapat menghilangkan nyawa seseorang, namun juga dapat merusak lingkungan komunitas serta merugikan keluarga dari korban sebagai korban sekunder. Hal ini dapat memengaruhi semua orang tanpa memandang usia, jenis kelamin, etnis maupun latar belakang sosial ekonominya. ${ }^{1}$ Berdasarkan 
data, keseluruhan risiko yang mengalami kematian akibat pembunuhan terus menurun pada seperempat abad terakhir ini. Namun, tingkat pembunuhan global dihitung sebagai proporsi populasi dan menurun hanya disebabkan karena populasi global meningkat. Jumlah kasus kejahatan pembunuhan di Indonesia selama periode lima tahun terakhir bersifat fluktuatif dengan kecenderungan menurun. Kejadian kejahatan pembunuhan di Indonesia pada tahun 2015 sampai 2018 mengalami penurunan dimana tercatat 1.491 kejadian pada tahun 2015 (tertinggi pada kurun waktu lima tahun terakhir). Angka ini menurun pada tahun 2016 menjadi 1.292 kejadian, tahun 2017 menjadi 1.150 kejadian, dan turun kembali menjadi 1.024 kejadian pada tahun $2018 .^{2}$

Dalam membahas tindak kejahatan perlu dipahami terlebih dahulu mengenai kriminologi yaitu kumpulan ilmu yang mempelajari tentang kejahatan, perilaku kriminal, motif, dan penyebab suatu tindak kejahatan. ${ }^{3}$ Definisi lain dari kriminologi adalah Criminology is the body of knowledge regarding delinquency and crime as social phenomena atau kriminologi merupakan kumpulan pengetahuan yang membahas mengenai kejahatan dan kenakalan sebagai fenomena sosial. Kriminologi bukan merupakan disiplin ilmu tunggal melainkan gabungan beberapa disiplin ilmu yang mencakup, filosofi, psikologi, ilmu politik, sosiologi, antropologi, biologi dan neuroscience. ${ }^{4}$

Kriminologi sendiri dibagi atas dua golongan besar yaitu: kriminologi teoritis dan kriminologi praktik. Dalam kriminologi teoritis terdapat kriminologi antropologi, sosiologi kriminal, psikologi kriminal, dan penologi sedangkan dalam kriminologi praktik terdapat criminal hygene, politik criminal, dan kriminalistik. ${ }^{5}$

Pemrofilan kejahatan (criminal profiling) merupakan cabang ilmu dari kriminologi forensik. Pemrofilan kejahatan mencakup pencarian hubungan antara karakteristik kriminal secara fisik, emosional, psikologi, kebiasaan dan vokasi. ${ }^{6}$

Selain itu, pemrofilan kejahatan juga melakukan penyimpulan rincian ciri-ciri fisik, demografis, dan keperilakuan dari kemungkinan pelaku kejahatan berdasarkan aksinya di tempat kejadian perkara (TKP). Data tempat kejadian dapat diperoleh dari foto, laporan penyelidikan, hasil autopsi, dan lain sebagainya, yang akan digunakan untuk menyusun suatu profil kejahatan dari pelaku tindak kejahatan. ${ }^{7}$

Objektif utama dari suatu pemrofilan kejahatan ialah untuk mengetahui suatu kelompok yang mungkin memiliki kecenderungan melakukan suatu tindak kejahatan. Berdasarkan tiga aspek penting dalam profiling kejahatan, modus operandi adalah suatu istilah pada profiling kejahatan yang merupakan kebiasaan dan metode suatu pelaku kejahatan dalam melakukan tindak kejahatan, menghindari deteksi pihak berwajib, atau memfalisitasi pelarian. ${ }^{8}$

Pada penyusunan profil kriminal akan terdapat kaitan dengan hal-hal seperti analisis bukti fisik yang ditemukan di tempat kejadian kejahatan, proses penggalian pemahaman mengenai korban (victimology), mencari modus operandi (apakah peristiwa kejahatan terencana atau tidak terencana), dan proses pencarian jejak pelaku kejahatan yang sengaja ditinggalkan (signature). ${ }^{9}$

Berdasarkan latar belakang yang telah dipaparkan maka penulis terdorong untuk mengetahui lebih mendalam mengenai profil pembunuhan di Kota Manado tahun 2018-2019

\section{METODE PENELITIAN}

Jenis penelitian yang dilakukan ialah deskriptif retrospektif dengan menggunakan laporan kasus pembunuhan di Polisi Resor Kota (Polresta) Manado tahun 2018-2019. Sampel penelitian yang diambil ialah semua data lengkap kasus pembunuhan yang terlapor di Polresta Manado pada periode tahun 2018-2019. Variabel penelitian ialah jenis kekerasan, jenis kelamin korban dan pelaku, kelompok usia korban dan pelaku, tingkat pendidikan dari korban dan pelaku, hubungan korban dengan pelaku, waktu kejadian, status Visum et Repertum (VeR), menurut kelengkapan berkas pengadilan, menurut motif, dan status autopsi. 


\section{HASIL PENELITIAN}

Berdasarkan hasil penelitian retrospektif yang telah dilakukan di Polresta Manado, tercatat jumlah kasus pembunuhan pada tahun 2018-2019 berdasarkan laporan yang masuk ialah sebanyak 17 kasus, yang terdiri dari 8 kasus pada tahun 2018 dan 9 kasus pada tahun 2019 yang dilaporkan.

Gambar 1 menunjukkan bahwa penyebab kematian tindak pidana pembunuhan dari 17 kasus yang terdata ialah 15 (88\%) kasus akibat kekerasan tajam, $1(6 \%)$ kasus akibat kekerasan tumpul, dan $1(6 \%)$ kasus lainnya.

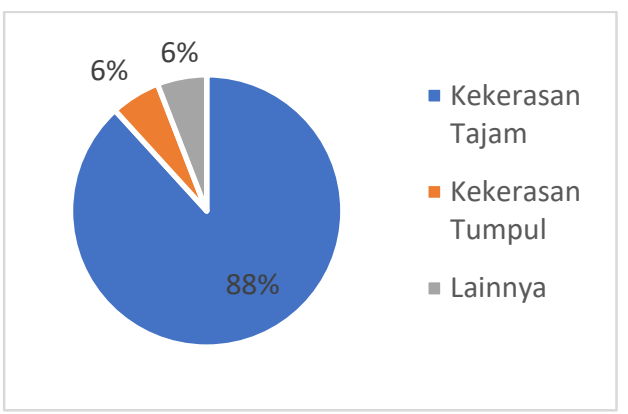

Gambar 1. Jumlah kasus pembunuhan di Kota Manado tahun 2018-2019 menurut jenis kekerasan

Gambar 2 memperlihatkan bahwa jenis kelamin korban pada 17 kasus semuanya $(100 \%)$ berjenis kelamin laki laki; tidak ada data untuk korban jenis kelamin perempuan.

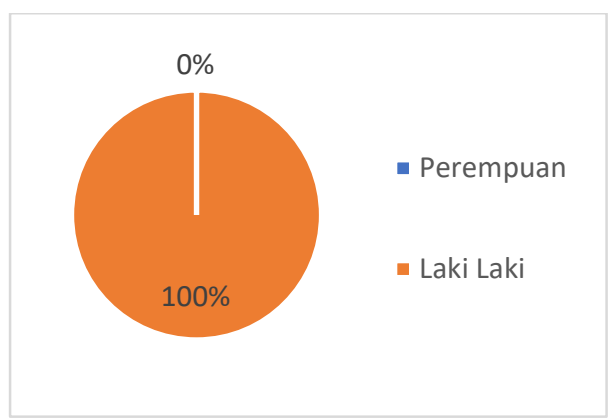

Gambar 2. Jumlah kasus pembunuhan di Kota Manado Tahun 2018-2019 menurut jenis kelamin korban

Gambar 3 memperlihatkan bahwa menurut jenis kelamin pelaku didapatkan 16 (94\%) kasus berjenis kelamin laki-laki dan $1(6 \%)$ kasus berjenis kelamin perempuan.

Gambar 4 memperlihatkan bahwa jumlah kasus berdasarkan usia didominasi usia
17-25 tahun sebanyak 9 (53\%) kasus sedangkan yang paling sedikit ialah usia 1216 tahun sebanyak 1 (6\%) kasus

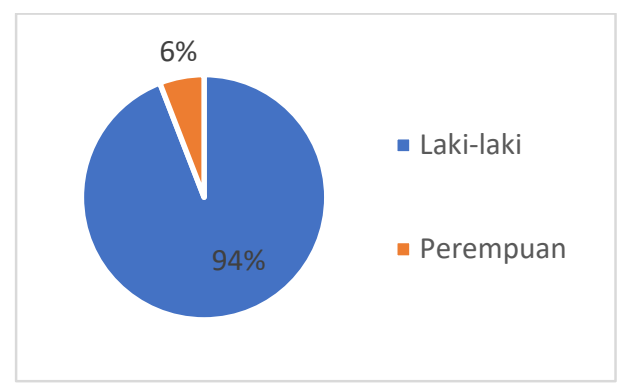

Gambar 3. Jumlah kasus pembunuhan di Kota Manado tahun 2018-2019 menurut jenis kelamin pelaku

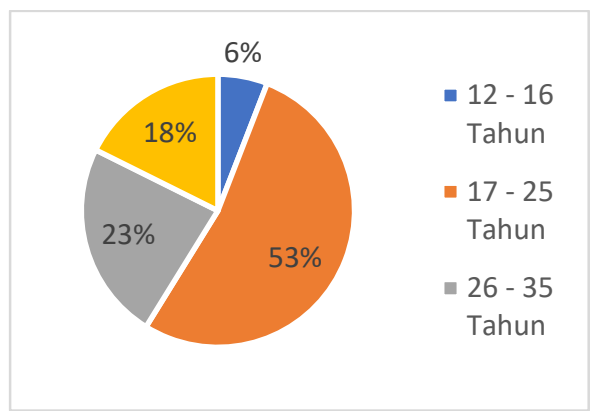

Gambar 4. Jumlah kasus pembunuhan di Kota Manado tahun 2018-2019 menurut usia korban

Gambar 5 memperlihatkan bahwa berdasarkan usia pelaku jumlah kasus masih didominasi usia 17-25 tahun sebanyak 10 (59\%) kasus, sedangkan yang paling sedikit ialah usia 12-16 tahun dan usia 36-46 tahun masing-masing sebanyak $1(6 \%)$ kasus.

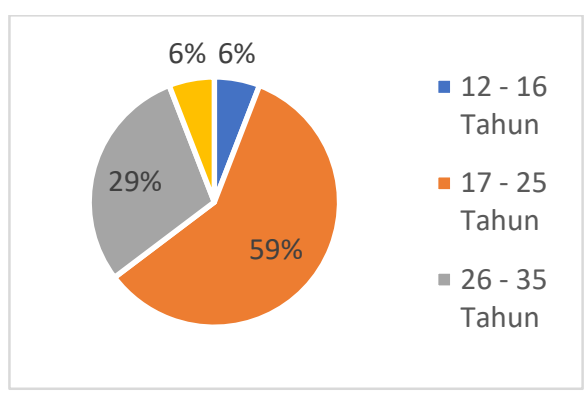

Gambar 5. Jumlah kasus pembunuhan di Kota Manado tahun 2018-2019 menurut usia pelaku

Gambar 6 memperlihatkan bahwa jumlah kasus pembunuhan berdasarkan waktu kejadian lebih cenderung pukul 00.00-05.59 WITA dengan jumlah sebanyak 9 (53\%) kasus, pukul 06.00-11.59 sebanyak 1 (6\%) 
kasus, pukul 12.00-17.59 sebanyak $2(12 \%)$ kasus, dan pukul 18.00-23.59 sebanyak 5 $(29 \%)$ kasus.

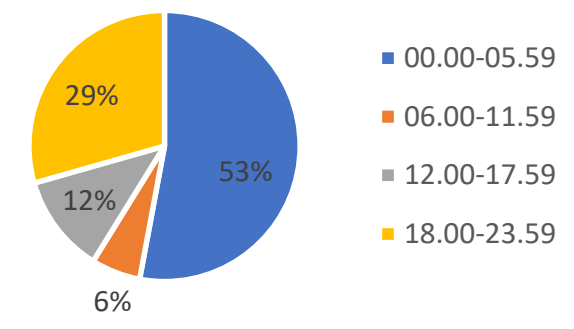

Gambar 6. Jumlah kasus pembunuhan di Kota Manado tahun 2018-2019 menurut waktu kejadian

Gambar 7 memperlihatkan bahwa jumlah kasus berdasarkan tingkat pendidikan terakhir korban terlihat bahwa jenjang SMA memiliki jumlah kasus tertinggi yaitu 15 $(88 \%)$ kasus, pendidikan SMP di tempat kedua yaitu $2(12 \%)$ kasus, sedangkan untuk Strata 1 tidak ada data.

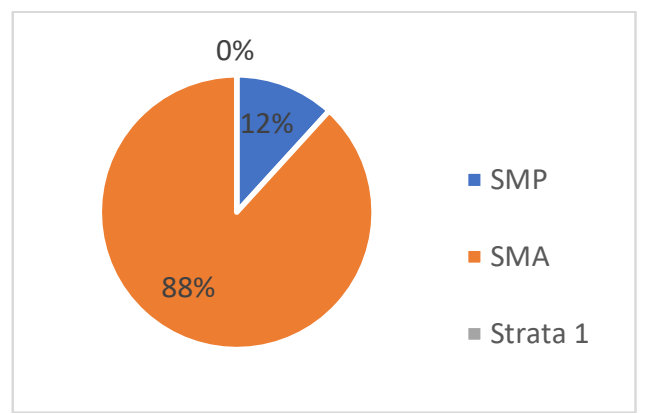

Gambar 7. Jumlah kasus pembunuhan di Kota Manado tahun 2018-2019 menurut status pendidikan terakhir korban

Gambar 8 memperlihatkan bahwa untuk jumlah kasus berdasarkan tingkat pendidikan terakhir pelaku terlihat bahwa jenjang SMA memiliki jumlah kasus tertinggi yaitu 14 (82\%) kasus, pendidikan SMP di tempat kedua yaitu $3(18 \%)$ kasus sedangkan untuk Strata 1 tidak ada data.

Gambar 9 memperlihatkan bahwa jumlah kasus menurut status visum memiliki angka yang sangat baik yaitu pada 17 kasus yang diteliti, kesemuanya $(100 \%)$ telah divisum. Tidak terdapat data untuk kasus yang belum dilakukan visum.

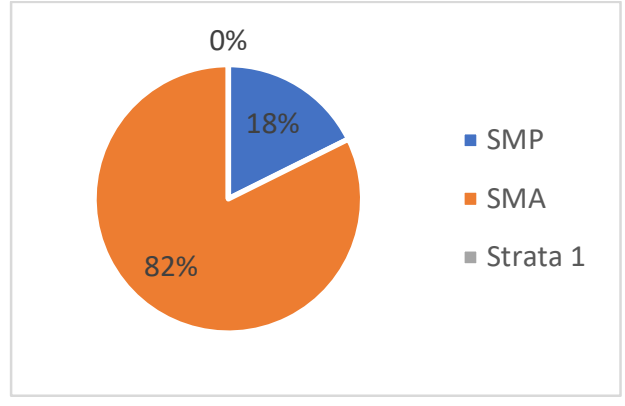

Gambar 8. Jumlah kasus pembunuhan di Kota Manado tahun 2018-2019 menurut status pendidikan pelaku

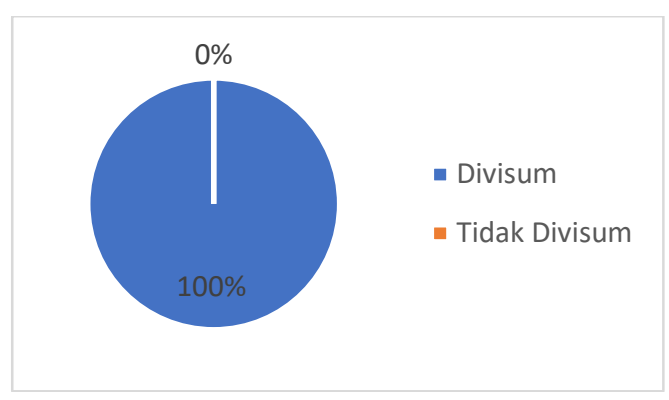

Gambar 9. Jumlah kasus pembunuhan di Kota Manado tahun 2018-2019 menurut status visum et repertum

Gambar 10 memperlihatkan bahwa untuk jumlah kasus menurut kelengkapan berkas dan barang bukti, dari 17 kasus yang diteliti semua $(100 \%)$ kasus memiliki kelengkapan berkas untuk dilakukan persidangan.

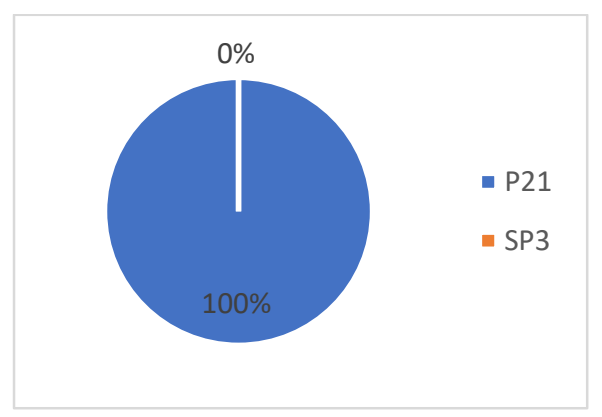

Gambar 10. Jumlah kasus pembunuhan di Kota Manado tahun 2018-2019 menurut kelengkapan berkas

Gambar 11 memperlihatkan bahwa jumlah kasus menurut motif di Kota Manado masih memiliki kencenderungan akibat dendam dengan jumlah kasus sebanyak $9(53 \%)$ kasus dan untuk sakit hati sendiri sebanyak $8(47 \%)$ kasus.

Gambar 12 memperlihatkan bahwa jum- 
lah kasus pembunuhan menurut hubungan korban terhadap pelaku didapatkan yang terbanyak ialah teman dengan jumlah kasus sebanyak 10 (59\%) kasus, suami istri dengan jumlah kasus $1(6 \%)$, dan tidak dikenal sebanyak $6(35 \%)$ kasus.

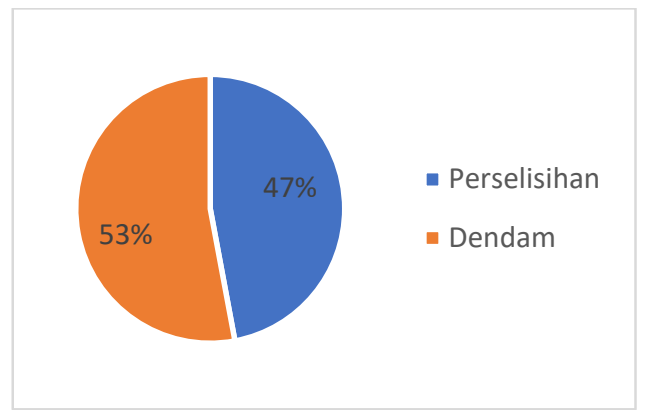

Gambar 11. Jumlah kasus pembunuhan di Kota Manado tahun 2018-2019 menurut motif

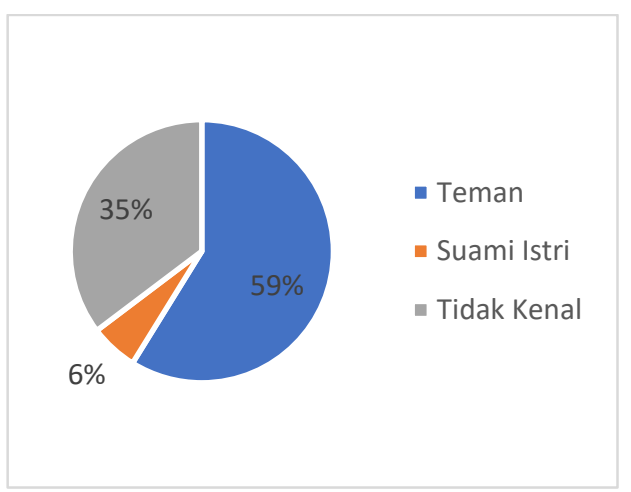

Gambar 12. Jumlah kasus pembunuhan di Kota Manado tahun 2018-2019 menurut hubungan korban terhadap pelaku

Gambar 13 memperlihatkan bahwa jumlah kasus pembunuhan menurut status autopsi didapatkan yang terbanyak ialah diautopsi sebanyak 13 (76\%) kasus, serta tidak diautopsi sebanyak 4 kasus 4 (24\%)

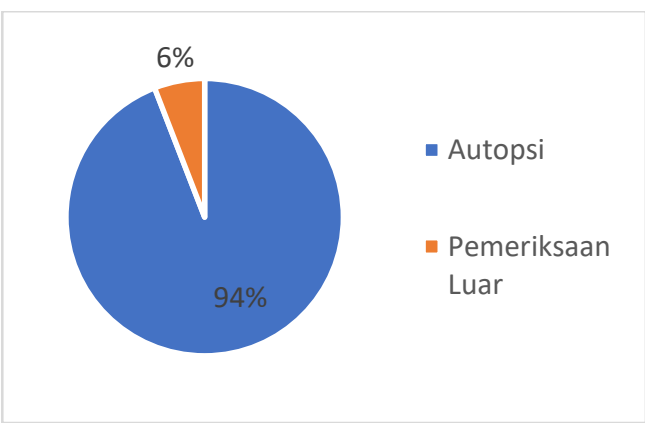

Gambar 13. Jumlah kasus pembunuhan di Kota Manado tahun 2018-2019 menurut status autopsi

\section{BAHASAN}

Pada penelitian ini didapatkan penurunan angka kasus pembunuhan merujuk pada penelitian sebelumnya yang dilakukan di Bagian Forensik RSUP Prof. Dr. R. D. Kandou Malalayang pada tahun 2015 yaitu terdapat 34 kasus pembunuhan, tahun 2016 sebanyak 21 kasus, dan pada tahun 2017 sebanyak 32 kasus. ${ }^{10,11}$ Angka kasus pembunuhan pada tahun 2018 sesuai dengan yang didapatkan di Polresta Manado sebanyak 8 kasus dan pada tahun 2019 dengan lokasi yang sama didapatkan sebanyak 9 kasus, dengan total kasus tahun 2018-2019 sebanyak 17 kasus. Dengan demikian terdapat penurunan sebanyak 38\% di tahun 2015 ke 2016, dan penurunan sebanyak $62 \%$ pada tahun 2016 ke tahun 2018. Bila dibandingkan penurunannya dari tahun 2015 ke tahun 2018 terdapat lebih dari $76 \%$.

Dinilai dari sebab kematian yang didominasi oleh kekerasan tajam, bila dibandingkan dengan penelitian di RSUP Prof. Dr. R. D. Kandou Malalayang tahun 2015 yaitu terdapat 24 kasus pembunuhan dengan kekerasan tajam dari 34 kasus pembunuhan, sedangkan pada data kasus pembunuhan tahun 2018-2019 didapatkan 15 kasus dari 17 kasus pembunuhan; keduanya mencapati lebih dari $80 \%$ untuk kasus pembunuhan menggunakan senjata tajam pada tiap kasus pembunuhan. ${ }^{11}$

Sesuai dengan data yang diperoleh hampir semua korban dan pelaku tindak pembunuhan memiliki jenis kelamin laki laki. Pada penelitian School of Criminology and Criminal Justice, Northeastern University, Boston, Massachusetts tahun 2017 dilaporkan bahwa $90 \%$ dari pada pelaku pembunuhan memiliki jenis kelamin lakilaki dan $81 \%$ korban pembunuhan memiliki jenis kelamin laki-laki. ${ }^{12}$

Usia juga dapat berperan pada tindak pembunuhan. Sesuai dengan penelitian School of Criminology and Criminal Justice, Northeastern University, Boston, Massachusetts tahun 2017, didapatkan bahwa usia pelaku tindak pembunuhan didominasi oleh usia lebih dari 25 tahun yaitu $>50 \%$, untuk usia 18-24 tahun sebanyak 40\%, dan usia 
14-17 tahun sebanyak kurang lebih 10\%, sedangkan untuk korban tindak pembunuhan masih di dominasi oleh usia lebih dari 25 tahun sebesar $64 \%$, usia $18-24$ sebesar $27 \%$, usia 14-17 tahun sebesar 5\%, dan usia kurang dari 14 tahun sebesar $4 \% .{ }^{12}$ Hal ini sejalan dengan data yang didapatkan yaitu kelompok usia yang sering terlibat tindak pembunuhan ialah 18-35 tahun dengan total sebanyak 13 kasus bagi korban dan 15 kasus bagi pelaku.

Waktu terjadinya tindak kejahatan turut berpengaruh terhadap risiko terjadinya tindak pembunuhan. Menurut penelitian oleh Department of Psychology, University of Cagliari, Cagliari, risiko terjadinya tindak pembunuhan meningkat dengan pertambahan waktu dari pagi, sore, malam sampai tengah malam dengan jumlah kasus, pukul 06.00-11.59 didapatkan rerata sebanyak 97,8 kasus pertahun; pukul 12.00-17.59 didapatkan rerata kasus sebanyak 98,8 kasus pertahun; pukul 18.00-23.59 didapatkan rerata kasus sebanyak 104,2 kasus pertahun; dan pukul 24.00-05.59 didapatkan rerata kasus sebanyak 173.7 kasus pertahun. Hal ini dapat dipengaruhi oleh ritme sirkadian yang memengaruhi ketidakmampuan seseorang dalam mengontrol impuls. Seseorang dengan gangguan kontrol impuls mungkin lebih sering terlibat dalam perkelahian dan tindakan agresi lainnya. Sesuai dengan penelitian tersebut, waktu terjadinya tindak pembunuhan paling sedikit di pagi dan siang hari, kemudian meningkat mengikuti waktu dengan puncak pada tengah malam. ${ }^{13}$

Status pendidikan terakhir juga memengaruhi risiko seseorang dalam melakukan tindak pembunuhan. Penelitian yang dilakukan oleh Tchemi ${ }^{14}$ di Albany mendapatkan hubungan antara tingkat pendidikan dengan risiko seseorang melakukan tindak pidana pembunuhan. Bagi kelompok dengan edukasi mengenai kejahatan dan sanksi kejahatan yang kurang dapat meningkatkan angka risiko terjadinya tindak pembunuhan sebesar $14 \%$ dibandingkan dengan kelompok yang telah mempelajari mengenai kejahatan dan dampak dari kejahatan itu sendiri. Sesuai dengan penjelasan yang telah dipaparkan, ditemu- kan bahwa kebanyakan kasus pembunuhan terjadi dengan status pendidikan terakhir korban dan pelaku di jenjang SMA. Hal ini dapat diakibatkan karena kurangnya kesetaraan SMA di Kota Manado dan kurangnya pembelajaran moral.

Dalam tindak pembunuhan seringkali pelaku melakukan tindak pembunuhan akibat terdorong oleh motivasi motivasi tertentu, pada penelitian di Boston, U.S hampir 50\% tindak pembunuhan hanya berawal dari argument. di Kota Manado masih memiliki kencenderungan akibat dari dendam, dimana dengan jumlah kasus sebanyak 9 (53\%) kasus dan untuk perselisihan sendiri sebanyak 8 (47\%) kasus, jadi berdasarkan dengan data yang ada tindak pembunuhan masih lebih kearah reaktif dari pribadi masing-masing. ${ }^{12}$ Motivasi seperti dendam dan perselisihan merupakan motivasi paling utama seseorang melakukan pembunuhan berbeda dengan daerah daerah lain yang dapat berupa permasalahan hutang, perkelahian geng, dan motivasi lain.

Kelompok pertemanan berpengaruh penting terhadap risiko terjadi-nya tindak pembunuhan. Lingkungan tem-pat bergaul serta waktu saat beraktivitas dapat diperhatikan sebagai upaya mencegah terjadinya tindak pembunuhan. Dengan adanya kontak sering terpicu perselisihan antar teman yang dapat berakhir dengan tindak pembunuhan. Pembunuhan terhadap orang yang tidak dikenal juga cukup tinggi, dimana korban tidak mengenal pelaku secara pribadi melainkan melalui pihak ketiga (third party) yang dapat menjadi motif sehingga terjadinya suatu tindak pembunuhan. Pada penelitian ini didapatkan jumlah kasus pembunuhan menurut hubungan korban terhadap pelaku yang terbanyak ialah teman dengan jumlah kasus sebanyak $10(59 \%)$ kasus, sedangkan suami istri sebauyak $1(6 \%)$ kasus, dan tidak dikenal sebanyak $6(35 \%)$ kasus. Sumampouw et $\mathrm{al}^{11}$ juga mendapatkan hubungan antara pelaku dan korban yang terbanyak ialah teman yaitu sebanyak 55\%, diikuti oleh $33 \%$ orang asing, dan $12 \%$ keluarga. Hal ini juga sejalan dengan penelitian oleh Fox dan Fridel $^{12}$ yaitu mayoritas kasus yang memi- 
liki hubungan sebagai teman, diikuti oleh tindak pembunuhan oleh pihak yang tidak dikenal.

Dengan adanya tindak pembunuhan maka diperlukan suatu tindakan yaitu penyelidikan. Dalam proses penyelidikan diperlukan tindakan autopsi untuk mengetahui sebab pasti dari kematian seseorang. Hal inilah yang menjadi salah satu peran dari ilmu kedokteran forensik. Sesuai data yang didapatkan jumlah kasus yang dilakukan VeR sebanyak 17 (100\%) kasus dari 17 kasus yang diteliti. Dari angka tersebut total kasus yang di autopsi didapatkan 16 (94\%) kasus, dan 1 (6\%) kasus hanya dilakukan pemeriksaan luar. Angka tersebut terbilang baik bila dibandingkan dengan angka jumlah kasus autopsi pada penelitian terdahulu yaitu pada 34 kasus pembunuhan 26 kasus diautopsi dan 8 kasus yang tidak diautopsi. Berdasarkan data yang telah dikumpulkan, seluruh kasus yang dibuatkan VeR merupakan kasus yang telah lengkap berkas dan siap untuk diajukan ke pengadilan. Hal ini menunjukkan bahwa suatu autopsi dan VeT berperan penting sebagai media pembuktian suatu tindak pidana. Bila dibandingkan dengan penelitian yang dilakukan tahun 2015 maka terdapat adanya peningkatan angka autopsi. Hal ini menunjukkan bahwa kesadaran akan penegakan hukum untuk kejahatan terhadap nyawa dan tubuh sudah semakin lebih diperhatikan. ${ }^{15}$

\section{SIMPULAN}

Penyebab kematian akibat tindak pembunuhan tertinggi disebabkan oleh kekerasan tajam, diikuti dengan kekerasan tumpul, dan kekerasan suhu panas. Mayoritas korban dan pelaku pembunuhan memiliki jenis kelamin laki-laki, usia 17-35 tahun, dan tingkat pendidikan SMA. Risiko terjadinya tindak pembunuhan meningkat sesuai dengan semakin larutnya hari.

Penyelidikan diperlukan untuk menindaklanjuti kasus tindakan pembunuhan. Penyelidikan seperti autopsi dan pemeriksaan luar dalam pembuatan Visum Et Repertum diperlukan untuk mengetahui sebab kematian seseorang dan sebagai bukti tertulis suatu tindak pidana.

\section{Konflik Kepentingan}

Penulis menyatakan tidak terdapat konflik kepentingan dalam studi ini.

\section{DAFTAR PUSTAKA}

1. Vazsonyi A, Wittekind J, Belliston L, Loh T. Global study on homicide. Unodoc. 2014;20:1-125.

2. Badan Pusat Statistik (BPS). Cover statistik kriminal 2019. Available from: https:// www.bps.go.id/publication/2019/12/12/ 66c0114edb7517a33063871f/statistikkriminal-2019.html.

3. Priyatno HD. Kriminologi Perspektif Hukum Pidana. Jakarta Timur: Sinar Grafika, 2019; p. 252.

4. Alam AS. Pengantar Kriminologi. Jakarta: IKAPI, 2010.

5. Soesilo RT. Kriminologi. Bogor: Politea, 2010.

6. Fulero S. Forensic Psychology. e-conversion Proposal for a Cluster of Excellence. California: Nelson Education, 2009.

7. Arigo B. Introduction to Forensic Psychology [Internet]. London: Academic Press; 2003. Available from: http://library1.nida. ac.th/termpaper6/sd/2554/19755.pdf

8. Swart J. Criminal Profiling. Detroit: Lilit Publishing; 2015.

9. Godwin M. Criminal psychology and forensic technology: a collaborative approach to effective profiling. Journal of Chemical Information and Modeling. 2000;53: 1689-99.

10. Ango CP, Tomuka D, Kristanto E. Gambaran sebab kematian pada kasus kematian tidak wajar yang diautopsi di RS Bhayangkara Tingkat III Manado dan RSUP Prof. Dr. R. D. Kandou Manado tahun 2017-2018. e-CliniC. 2019;8(1): $10-4$.

11. Sumampouw B, Siwu J, Mallo J. Kasus kematian yang diakibatkan oleh pembunuhan yang masuk Bagian Forensik RSUP Prof Dr. R. D Kandou Manado tahun 2015. J Kedokt Klin. 2017;1(2): 29-36.

12. Fox JA, Fridel EE. Gender differences in patterns and trends in U.S. homicide, 1976-2015. Violence Gend. 2017;4(2): 37-43.

13. Sisti D, Rocchi MBL, MacCiò A, Preti A. The epidemiology of homicide in Italy by season, day of the week and time of day. Med Sci Law. 2012;52(2):100-6.

14. Tcherni M. Structural determinants of homi- 
cide: the big three. J Quant Criminol. 2011;27(4):475-96.

15. Langie Y, Tomuka D, Kristanto EG. Peran visum et repertum dalam penegakan hukum pidana pada kasus kematian tidak wajar di Kota Manado. Jurnal Biomedik. 2015;7(1):48-53. 